\title{
Lhermitte-Duclos Disease and Cowden Syndrome: A Case Report and Literature Review
}

\section{Doença de Lhermitte-Duclos e Síndrome de Cowden: relato de caso e revisão da literatura}

\author{
Mylena Miki Lopes Ideta ${ }^{1}$ Mylla Christie Oliveira Paschoalino ${ }^{1} \quad$ Louise Makarem Oliveira $^{1}$ \\ Nelson Brancaccio dos Santos ${ }^{2}$ Marco Rodrigo Valdivia Sanz ${ }^{3}$ Robson Luis Oliveira de Amorim ${ }^{4}$
}

1 Universidade Federal do Amazonas, Manaus, AM, Brazil

2 Pontificia Universidade Católica de São Paulo, São Paulo, SP, Brazil

3 Hospital Dr. João Lúcio Pereira Machado, Manaus, AM, Brazil

4 Universidade Federal do Amazonas, Manaus, AM, Brazil
Address for correspondence Robson Luis Oliveira de Amorim, Al. Zaire, 50 ap 1202 CEP 69037061 Manaus-AM, (e-mail: amorim.robson@gmail.com).

Arq Bras Neurocir 2019;38:319-323.

\author{
Abstract \\ Keywords \\ - Lhermitte-Duclos \\ disease \\ - Cowden syndrome \\ - hamartoma \\ syndrome \\ - cerebellum
}

Lhermitte-Duclos disease (LDD), also known as dysplastic gangliocytoma of the cerebellum, is a rare, usually benign, slow-growing tumor, that commonly affects patients aged 30 to 50 years-old. The manifestations of dysplastic cerebellar gangliocytoma are nonspecific and are related both to the mass effect produced by its growth and to the location of the lesion. Cerebellar symptoms such as ataxia are often present. In $40 \%$ of cases, the tumor is associated with Cowden syndrome, which is part of a group of genetic disorders called polypoid hamartoma complex. In this case report, the patient presented expansive lesion in the posterior fossa, compatible with LDD, associated with macrocephaly. These findings are considered major criteria for Cowden syndrome. When together, they confirm the diagnoses. To our knowledge, this is the first report of the association of LDD and Cowden syndrome in Brazil.

A doença de Lhermitte-Duclos (DLD), também conhecida como gangliocitoma displásico do cerebelo, é um tumor raro, geralmente benigno e de lento crescimento, que geralmente afeta pacientes entre 30 e 50 anos. Suas manifestações são inespecíficas e se relacionam ao efeito de massa produzido por seu crescimento e pela localização da lesão. Comumente, observam-se sintomas cerebelares, como ataxia, dismetria e disdiadococinesia. Em 40\% dos casos, a doença encontra-se associada à síndrome de Cowden, a qual faz parte de um grupo de enfermidades genéticas chamado complexo do hamartoma polipoide. No caso relatado, o paciente apresentou lesão expansiva em fossa posterior compatível com DLD, associada à macrocefalia. Esses achados constituem dois critérios maiores, os quais, em conjunto, determinam o diagnóstico de Síndrome de Cowden. Este é o primeiro relato da associação entre DLD e Síndrome de Cowden no Brasil. received

August 30, 2018

accepted

May 27, 2019
DOI https://doi.org/

10.1055/s-0039-1693682.

ISSN 0103-5355.
Copyright $\odot 2019$ by Thieme Revinter

Publicações Ltda, Rio de Janeiro, Brazil
License terms

(c) $(1) \risingdotseq$ 


\section{Introduction}

Lhermitte-Duclos disease (LDD), also known as dysplastic gangliocytoma of the cerebellum, is a rare condition. Only 300 cases have been reported in the literature since its description in $1920 .^{1-3}$ This tumor, which is composed by atypical ganglion cells, is considered benign and slow-growing. ${ }^{4,5}$ It usually presents in patients aged between 30 and 50 years. The non-specific clinical picture is related to the location of the tumor and to the mass effect produced by its growth. Therefore, the most common symptoms result from cerebellar involvement. Headache, motor disorders, intracranial hypertension, and ataxia, as well as others, are frequently observed.

The crucial point of LDD is the possibility of association with Cowden syndrome (CS), which participates in a group of genetic syndromes called polypoid hamartoma syndrome. ${ }^{6}$ This rare and autosomal dominant disorder is characterized by the presence of multiple hamartomas, which confers an increased risk to developing other neoplasms. The features of CS include benign mucocutaneous lesions, such as trichilemmomas, acral keratoses, and papillomatous lesions, in addition to LDD-which was recognized as a major criterion for Cowden syndrome by the International Cowden Consortium Criteria, in 2004. ${ }^{7,8}$

As far as we know, there is no report of LDD associated with Cowden syndrome in Brazil. In the present work, we not only report this condition but also present the findings of our systematic review of the literature.

\section{Case Report}

A 26-year-old male, living in Manaus, Amazonas, presented at our hospital with progressive unsteadiness. At the moment of admission, he was unable to walk. The patient also reported persistent and gradually increasing headache. Neurological examination revealed preserved motor strength, as well as an ataxic gait, dysdiadochokinesia, hypermetria, and dysarthria. A left nystagmus was further noticed.

Computed tomography (CT) of the skull showed a hypodense lesion in the posterior fossa on the right cerebellar hemisphere. A T1 gadolinium-enhanced magnetic resonance imaging (MRI) demonstrated a lobulated non-enhanced mass lesion, characterized by alternated linear hyposignal and isosignal areas.

In T2-weighted sequences, the hyposignal and hypersignal bands formed a "tiger-striped" pattern, an aspect classically described in cases of LDD. The lesion compressed the fourth ventricle but did not determine hydrocephalus (- Fig. 1).

In light of the suspected diagnosis, it became valid to investigate the possibility of CS. A thorough physical examination revealed macrocephaly $(62 \mathrm{~cm}$ of circumference, 95th percentile), as well as asymptomatic papillomatous lesions on the penis glans. Sexually transmitted diseases were discarded.

After diagnosis, surgical excision of the tumor through right suboccipital craniotomy was performed. Following dural opening, the cerebrospinal fluid was drained next to the cisterna magna, and we performed a small corticectomy. The non-bleeding hardened lesion resection was subtotal,
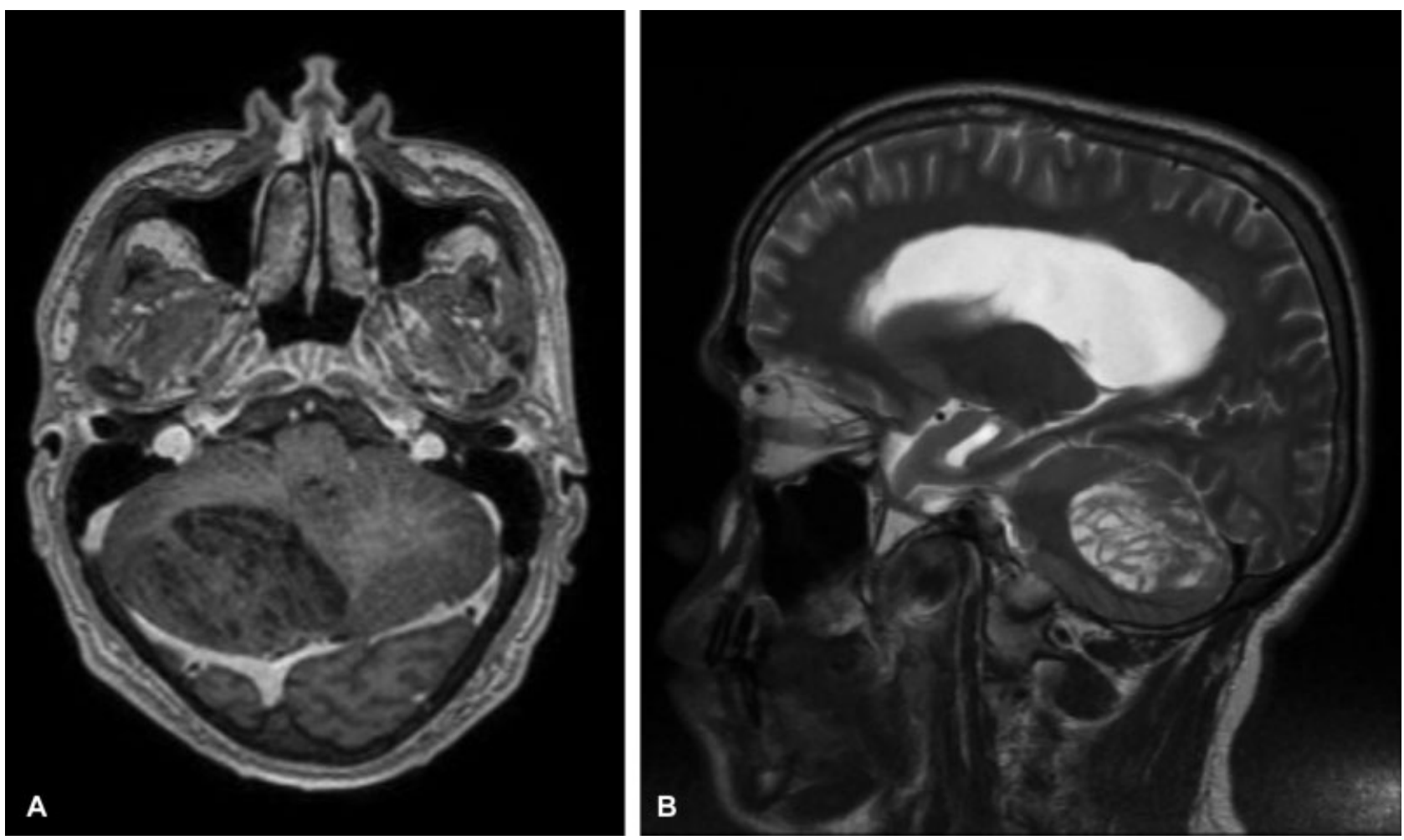

Fig. 1 Magnetic resonance imaging shows a non-contrasting expansive lesion in the right cerebellar hemisphere, with lamellar areas of intense hyposignal and isosignal in T1 with gadolinium (A). In T2 (B), the hyposignal and hypersignal bands reveal the striated pattern, referred to as "tiger-striped" sign, which is classically described in the cases of Lhermitte-Duclos disease. 


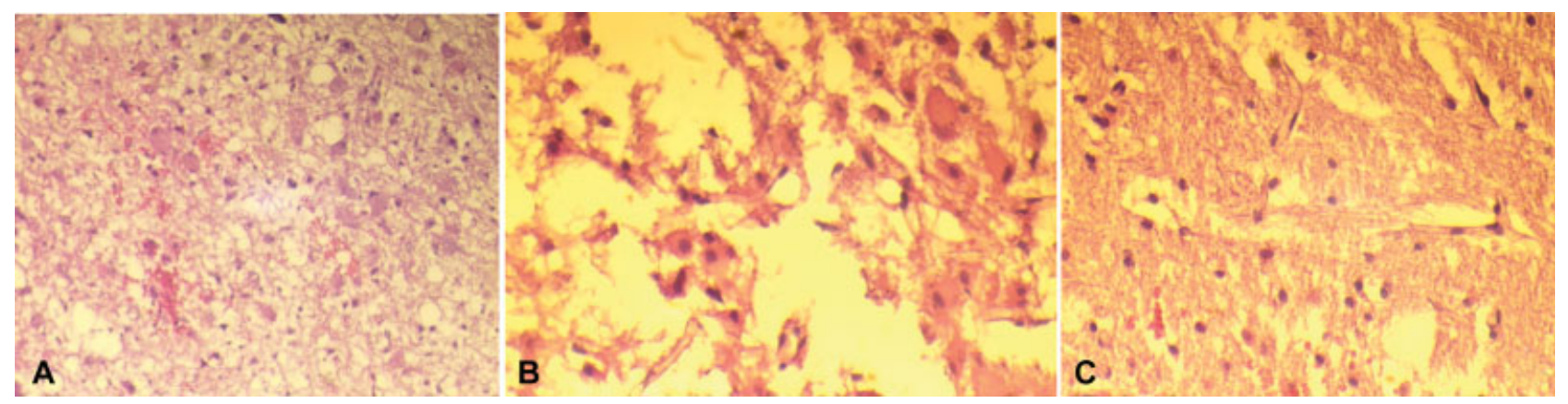

Fig. 2 Histopathological examination of the tumor (hematoxylin and eosin staining, original magnification of 200x). A and B: Polygonal cells with pleomorphic and cytoplasmic broad, eosinophilic nuclei, placed diffusely associated with vacuoles. C: normal glial cells of the same patient.

due to the absence of cleavage plane and difficult differentiation from the normal tissue.

In the histopathological study, proliferation of polygonal cells with pleomorphic nuclei, and broad and eosinophilic cytoplasm associated with vacuoles was observed. Hypertrophy of the cerebellar granular layer compatible with the diagnosis of dysplastic gangliocytoma of the cerebellum was further noticed. (- Fig. 2)

After treatment, the patient presented significant clinical improvement, with no cerebellar complaints and reduction of the headache. He has now completed 12 months of postoperative follow-up.

\section{Discussion}

For the literature review, we used the Medline and Lilacs databases to search relevant articles from the last review of the literature on the subject from 2006 until March 2019. We use the terms Lhermitte-Duclos disease, Lhermitte Duclos disease, Dysplastic gangliocytoma Cowden Disease, Dysplastic Gangliocytoma of the Cerebellum, and Cowden Syndrome. We identified 136 articles, and, of these, most were case reports (77 articles), and 2 articles were case series. So far, there are $\sim 300$ cases published in the literature. Of these, 5 reports are Brazilian. ${ }^{9-14}$ Therefore, this article is the 6th report of LDD and the first to report the association with CS in Brazil.

First described in the 1920s, there still is considerable controversy concerning the origin of LDD. It is known, however, that LDD is considered a major criterion of CS, an autosomal dominant genetic disorder.

Lhermitte-Duclos disease, or dysplastic gangliocytoma of the cerebellum, is a slow growing lesion of the cerebellum cortex, and it is usually diagnosed between the third and fourth decade of life, as identified in the present case, with no gender predominance. The expansive effect, associated with obstruction of cerebrospinal fluid flow, may result in noncommunicating hydrocephalus and intracranial hypertension. In addition, cerebellar symptoms, as in the case described, and cranial nerves involvement may occur.

The imaging examination is of great value during the diagnostic investigation of LDD. Although CT has significant limitations-showing a hypodense image without contrast enhancement-, the MRI associated with diffusion sequence and spectroscopy, shows a classic expansive lesion with hypo- signal on T1 and hypersignal on T2-weighted sequences. ${ }^{15}$ Another feature observed in T2-sequences is the characteristic "tiger-striped" pattern. These changes result from both the white matter atrophy and the granular cell layer thickening.

The preoperative diagnosis is given by the tiger striped pattern present in T2-weighted MRI scans, associated with expansive cerebellar lesion affecting a single hemisphere. The lesion is characterized by hyperdense parallel grooves that occur due to cerebellar foliation thickening secondary to cortical cell enlargement, as well as groove dysplasia, which are considered to be practically pathognomonic radiological signs of LDD. ${ }^{16,17}$

Cowden syndrome, characterized by Lloyd and Dennis in 1963 , should be investigated in patients diagnosed with LDD. ${ }^{18}$ The syndrome is a genetic disorder due to a mutation in the phosphatase and homologous tensin (PTEN) gene or in its promoter region. The disorder affects the PTEN gene in the 10q23.2 locus in $80 \%$ of the patients. In addition, most LDD patients have a deletion-type mutation of the PTEN gene, resulting in abnormal growth of granular cells. ${ }^{8,18}$ The clinical diagnosis of this condition is based on the major and minor criteria described below (-Table 1 ). The pathognomonic CS criteria are: mucocutaneous lesions (facial trichilemmomas, papillomatous lesions, acral keratosis and mucosal lesions). The major criteria include: breast cancer, thyroid carcinoma (especially follicular type), macrocephaly (occipital-frontal circumference $\geq 97$ th percentile), endometrial carcinoma and LDD. Minor criteria include: other thyroid lesions, decreased intellectual capacity (IQ $\leq 75$ ), hamartomatous intestinal polyps, fibrocystic breast disease, lipomas, fibroids, tumors of the genitourinary tract (mainly renal cell carcinoma), genitourinary malformation, and uterine myoma. Therefore, the patient reported in the present case presents CS since it has 2 major criteria (LDD and macrocephaly), which define the diagnosis. The importance of the association relies on the fact that this disease determines a high risk of both benign and malignant neoplasms development. The thyroid, breast and endometrium are the main organs affected by the aforementioned neoplasms. Therefore, those patients should be closely monitored by a multidisciplinary team for surveillance of possible neoplasms that may occur.

The definitive treatment of LDD is surgical resection with decompression of the posterior fossa by total or subtotal tumor removal. Complete resection of the tumor is difficult due to the 
Table 1 Diagnosis criteria of Cowden syndrome

\begin{tabular}{|c|c|c|}
\hline Pathognomonic criteria & Major criteria & Minor criteria \\
\hline $\begin{array}{l}\text { Mucocutaneous lesions: } \\
\text { - Facial trichilemmomas } \\
\text { - Acral keratoses } \\
\text { - Papillomatous papules } \\
\text { - Mucosal lesions }\end{array}$ & $\begin{array}{l}\text { Breast cancer } \\
\text { Non-medullary thyroid cancer } \\
\text { Macrocephaly } \\
\text { Endometrial Cancer } \\
\text { Lhermitte-Duclos disease }\end{array}$ & $\begin{array}{l}\text { Benign thyroid lesions (goiter/nodules) } \\
\text { Mental retardation } \\
\text { Hamartomatous intestinal polyps } \\
\text { Lipomas } \\
\text { Fibrocystic breast disease } \\
\text { Fibromas } \\
\text { Genitourinary tumors or malformations }\end{array}$ \\
\hline \multicolumn{3}{|c|}{$\begin{array}{l}\text { Operational clinical diagnostic criteria for an individual: } \\
\text { 1) Pathognomonic mucocutaneous lesions alone if: } \\
\text { a. Six or more facial papules, at least three of which are biopsy-confirmed trichilemmomas, or } \\
\text { b. Cutaneous facial papules plus oral mucosal papillomatosis, or } \\
\text { c. Oral mucosal papillomatosis plus acral keratoses, or } \\
\text { d. Six or more palmoplantar keratoses } \\
\text { 2) Two or more major criteria, one of which must be macrocephaly or Lhermitte-Duclos disease } \\
\text { 3) One major plus three minor criteria } \\
\text { 4) Four minor criteria }\end{array}$} \\
\hline
\end{tabular}

Adapted from MESTER, 2014.

impossibility of clearly defining its margins. ${ }^{19,20}$ In the largest series published to date, Jiang et $\mathrm{al}^{19}$ evaluated 18 patients with LDD. Complete resection was possible in 9 of the 17 operated patients, and there was no recurrence in the late follow-up. Cowden syndrome was diagnosed in 11 of these 18 patients. Despite the degree of resection (partial or subtotal), the outcome is favorable, and recurrence is rare. ${ }^{19,20}$

In the second largest published series, Wang et $\mathrm{al}^{20}$ evaluated 12 patients, and a complete resection was achieved in 3 patients. Only one recurrence was reported. In cases of asymptomatic patients incidentally diagnosed by MRI, conservative management may also be assumed. ${ }^{21,22}$ The real effectiveness of posterior fossa irradiation therapy is unknown. However, assuming the non-neoplastic etiology of LDD, irradiation is unlikely beneficial, and, therefore, it is not recommended-even in subtotal resections. ${ }^{19,23}$

Moreover, in the histopathological examination, which is the gold standard for diagnosis, the white mass atrophy and the granular cell layer thickening can be observed. ${ }^{2,6}$ The absence of the Purkinje, the laminar cytoarchitecture destruction of the cerebellar cortex, and the presence of hypertrophic and dysplastic neurons in the internal granular layer are common findings. On the other hand, the absence of mitotic activity, necrosis, and endothelial proliferation indicate the benign nature of the lesion.

\section{Conclusion}

Lhermitte-Duclos disease is considered a rare cause of progressive headache, associated with cerebellar symptoms. When it comes to preoperative diagnosis, the T2-weightened MRI, which can demonstrate the classical "tiger-striped" pattern, is the preferential exam. The definitive diagnosis, nonetheless, is histopathological, and it results from the demonstration of a laminar cytoarchitecture destruction, as well as from the presence of hypertrophic and dysplastic neurons in the internal granular layer, and the absence of the Purkinje cell layer. The treatment can be either surgical or not. While tumor resection is recommended for all symptomatic patients, a conservative management may be considered for incidentally diagnosed asymptomatic patients. Physicians must remember to search the association with CS, which justifies a regular follow-up of the patient due to the risk of developing malignant lesions in other organs, such as the breast, the colon, and the thyroid.

Conflict of Interest

The authors declare that there is no conflict of interest.

\section{References}

1 Assarzadegan F, Gharib A, Behbahani S, Ebrahimi-Abyaneh M. Intracranial hypertension and cerebellar symptoms due to Lhermitte-Duclos disease. Iran J Neurol 2015;14(02):113-115

2 Giorgianni A, Pellegrino C, De Benedictis A, et al. LhermitteDuclos disease. A case report. Neuroradiol J 2013;26(06): 655-660

3 Murray C, Shipman P, Khangure M, et al. Lhermitte-Duclos disease associated with Cowden's syndrome: case report and literature review. Australas Radiol 2001;45(03):343-346

4 Yang MS, Kim CH, Cheong JH, Kim JM. Lhermitte-Duclos Disease Presenting with Hydrocephalus. In: Acta neurochirurgica Supplement. 2012:161-5

5 Huang S, Zhang G, Zhang J. Similar MR imaging characteristics but different pathological changes: a misdiagnosis for LhermitteDuclos disease and review of the literature. Int J Clin Exp Pathol 2015;8(06):7583-7587

6 Uppal S, Mistry D, Coatesworth AP. Cowden disease: a review. Int J Clin Pract 2007;61(04):645-652

7 Blumenthal GM, Dennis PA. PTEN hamartoma tumor syndromes. Eur J Hum Genet 2008;16(11):1289-1300

8 Pilarski R, Burt R, Kohlman W, Pho L, Shannon KM, Swisher E. Cowden syndrome and the PTEN hamartoma tumor syndrome: systematic review and revised diagnostic criteria. J Natl Cancer Inst 2013;105(21):1607-1616

9 Robinson S, Cohen AR. Cowden disease and Lhermitte-Duclos disease: an update. Case report and review of the literature. Neurosurg Focus 2006;20(01):E6

10 da Silva AA, Banerjee T, Coimbra RL. Lhermitte-Duclos disease (cerebellar gangliocytoma). South Med J 1996;89(12):1208-1212 
11 Mattozo CA, De Borges LMC, Possebom AC, Santos QT. Patient with Lhermitte Duclos and meningioma, possible diagnosis of Cowden Syndrome. Revista Brasileira de Neurologia e Psiquiatria. 2013;7 (03):112-120

12 Pinto Wde R, Souza PV. Brain MRI features in Lhermitte-Duclos disease. Arq Neuropsiquiatr 2014;72(08):645-645

13 Uygur S, Andrade MC, Brum Cde AI, Monerat ALC, Landeiro JA, Acioly MA. Lhermitte-Duclos disease. Arq Neuropsiquiatr 2014; 72(05):392-393

14 Delgado NJ, Lessa AS, Carmo THL, et al. Advanced Imaging Techniques in Lhermitte-Duclos Disease (LDD): A Case Report and Brief Literature Review. Neurosci Med 2017;8(01):1-7

15 Pezzolesi MG, Zbuk KM, Waite KA, Eng C. Comparative genomic and functional analyses reveal a novel cis-acting PTEN regulatory element as a highly conserved functional E-box motif deleted in Cowden syndrome. Hum Mol Genet 2007;16(09):1058-1071

16 Nowak DA, Trost HA. Lhermitte-Duclos disease (dysplastic cerebellar gangliocytoma): a malformation, hamartoma or neoplasm? Acta Neurol Scand 2002;105(03):137-145

17 Nagaraja S, Powell T, Griffiths PD, Wilkinson ID. MR imaging and spectroscopy in Lhermitte-Duclos disease. Neuroradiology 2004; 46(05):355-358
18 Mester J, Eng C. Cowden syndrome: recognizing and managing a not-so-rare hereditary cancer syndrome. J Surg Oncol 2015;111 (01):125-130

19 Jiang T, Wang J, Du J, et al. Lhermitte-Duclos Disease (Dysplastic Gangliocytoma of the Cerebellum) and Cowden Syndrome: Clinical Experience From a Single Institution with Long-Term FollowUp. World Neurosurg 2017;104:398-406

20 Wang Q, Zhang S, Cheng J, Liu W, Hui X. Lhermitte-Duclos disease: Clinical study with long-term follow-up in a single institution. Clin Neurol Neurosurg 2017;162:53-58

21 Capone Mori A, Hoeltzenbein M, Poetsch M, Schneider JF, Brandner S, Boltshauser E. Lhermitte-Duclos disease in 3 children: a clinical long-term observation. Neuropediatrics 2003;34(01): 30-35

22 Marano SR, Johnson PC, Spetzler RF. Recurrent Lhermitte-Duclos disease in a child. Case report. JNeurosurg 1988;69(04): 599-603

23 Khandpur U, Huntoon K, Smith-Cohn M, Shaw A, Elder JB. Bilateral Recurrent Dysplastic Cerebellar Gangliocytoma (Lhermitte Duclos Disease) in Cowden Syndrome: A Case Report and Literature Review. World Neurosurg 2019:S1878-8750(19) 30809-5 